\title{
Boistimulator effect of stress tolerant rhizobacteria on horticultural models
}

\author{
Gerőcs A. ${ }^{1}$, Alshaal T. ${ }^{1,2}$, Elhawat N.,3, Fári M. ${ }^{1}$ \& Domokos-Szabolcsy É. ${ }^{1}$ \\ ${ }^{l}$ Department of Agricultural Botanics, Plant Physiology and Biotechnology, University of Debrecen, Hungary; \\ ${ }^{2}$ Department of Soil Science, Faculty of Agriculture, University of Kafrelsheikh, Egypt; \\ ${ }^{3}$ Department of Biological and Environmental Sciences, Faculty of Home Economics, Al-Azhar University, Egypt
}

\begin{abstract}
Summary: The tolerant bacteria for abiotic stresses such salinity, drought, and different $\mathrm{pH}$ have been used as a good tool to improve plant growth in sustainable agriculture. A pot experiment was conducted to evaluate the potential of isolated stresstolerant bacteria for red mud-polluted soil on growth performance of giant reed plants with increasing concentrations of $\mathrm{NaCl}$ $0.0 ; 0.1 ; 0.2 ; 0.3 ; 0.5 ; 1.0 \%$ under gnotobiotic conditions. At the same time biostimulator potential of isolated bacteria was observed in case of radish in vitro germination experiment under salt stress. It was found that the observed bacterial strain can tolerate the salt and $\mathrm{pH}$ moderately however it is resistant against hydrogen-peroxide caused oxidative stress in high concentration (up to $2640 \mathrm{mM}$ ). Molecular identification, basis on 16S rDNA showed $98 \%$ similarity to the Bacillus aryabhattai bacterial strain. The isolated strain alleviated the negative effect of salt $(0.05 \%)$ for the radish seed germination. However in higher salt concentration $(\geq 0.1 \%)$ the bacterial mitigating effect vanished. The inhibition of increasing salt concentration for giant reed plantlets was also alleviated by halotolerant bacteria treatment $(\geq 0.5 \%)$.
\end{abstract}

Keywords: halotolerant bacteria, salt tolerance, radish, Arundo donax L., stress alleviation

\section{Introduction}

Due to the unique genetic characteristics that prokaryotes including bacteria possess, they are able to easily adapt and survive under extreme environmental conditions such as drought, salinity and wide ranges of $\mathrm{pH}$. It is the vitality in the agro-ecosystems that researchers are investigating for opportunities to enhance agricultural inputs in the form of Plant Growth Promoting Rhizobacteria (PGPR). The products of PGPR can be a significant component of management practices to achieve the attainable yield in degraded soil. The success lies in their aggressive root colonization potential around the rhizosphere. The stress adaptability of microbes is due to sophisticated signalling system that microbes have for eliciting an adaptive response to stresses. The most dramatic of these behaviours are the purposeful migration or movement of the cells toward favourable conditions. Also, such bacteria can be exploited as a successful strategy for protecting the plants against the deleterious effects caused by soil-and seed-borne deleterious plant pathogens. Thus, the PGPR biotechnologies can be exploited as a low input, sustainable, and environmentally friendly technology for stress management in plants (Maheshwari, 2012).

For decades, agriculture, in areas that suffer from water scarcity such arid and semiarid environments, has faced a serious problem with increasing soil salinity. Salt is a necessary element for all life, but too much can be a problem. Saline soils will have a relatively high number of sodium ions compared to healthy soils. Excessive salt not only destroys the soil structure, but it also attracts water and blocks its absorption to plant roots. As a result, plants may exhibit signs of drought even when the soil is wet or waterlogged. Soil salinity is a major abiotic stress in plant agriculture strongly, influencing plant productivity worldwide. Just as the results of high soil salinity on plants are seen in leaf and stem burns, it is hard on earthworms and microorganisms as well (Khan and Panda 2008). The total salt-affected land worldwide is estimated to be 900 million ha, 6\% of the total global land mass (Flowers 2004). According to the Food and Agricultural Organization (FAO), if corrective measures are not taken, salinization of arable land will result in $30 \%$ land loss in the next 25 years and up to $50 \%$ by the year 2050 (Munns 2002). Salinity prevents plants from taking up water, exposing them to drought stress. These stresses have an adverse effect on plants, hampering their growth and finally production. Soil salinity is defined as the concentration of dissolvable salts extracted from soil by water (Richards 1954). Natural boundaries imposed by soil salinity also limit the caloric and the nutritional potential of agricultural production. These constraints are most acute in the areas devoted to agriculture; therefore, the urgent need of biological agents (bio-preparations) is accepted worldwide. Interest in the use 
of such bio-preparations that replenish the soil, add value, and enhance production and yield in saline conditions is the primary recommendation.

Giant reed (Arundo donax L.) is a perennial rhizomatous grass (Poaceae family), native to the freshwater regions of Eastern Asia, but nowadays considered as a subcosmopolitan species given its worldwide distribution (Bell, 1997; Alshaal et al. 2013a). It is a hydrophyte, growing along lakes, streams, drains and other wet sites. The genus Arundo is able to reach the height of $14 \mathrm{~m}$ and is among the fastest-growing terrestrial plants. It can produce more than $50 \mathrm{t} \mathrm{ha}^{-1}$ aboveground dry biomass (Tucker, 1990; Sharma et al., 1998; Günes and Saygin, 1996). As a consequence of its high and fast biological productivity, giant reed is widely cultivated to yield non-food crop that can meet requirements for energy, paper pulp production, bio-fuels and construction of build materials, but it has other different uses such as music tools with stem, medicine with roots and soil erosion control through re-vegetation.

Arundo displays unique physiological features whereby it readily absorbs and concentrates toxic chemicals from contaminated soil with no appreciable harm to its own growth and development (Perdue, 1958; Alshaal et al. 2013b). It is one of the mostly used plants as a trace element bioaccumulator, especially via phytoremediation processes, due to its capacity of absorbing contaminants such as metals that cannot be easily biodegraded. Giant reed can grow in different environments with spacious ranges of $\mathrm{pH}$, salinity, drought and trace metals without any symptoms of stresses and can easily adapt to different ecological conditions and grow in all types of soils. However, because of its great adaptability to different ecological conditions, giant reed is considered noxious invasive weeds in riparian habitats throughout the world (Coffman et al., 2010).

The present study was conducted in an attempt to identify and characterize salt and $\mathrm{pH}$ tolerant bacteria that is isolated from naturally red mud-polluted soil for its numerous PGP traits. Isolated strain was then checked for its ability to ameliorate saline stress under gnotobiotic conditions using Arundo plants and it. Alleviating effect of isolated strain was also observed in radish in vitro germination experiment under salt stress.

\section{Materials and methods}

\subsection{Soil sampling and isolation of bacteria after steam- ing process}

On October 4, 2010, the western dam of the red mud reservoir of an alumina plant in Ajka (Hungary) collapsed. Hungarian Aluminium Company (MAL) reported that About $700.000 \mathrm{~m}^{3}$ of the red mud/water mixture with a $\mathrm{pH}$ of about 12 was released from the reservoir. Two weeks after the Alumina factory catastrophe, a composite red mud-polluted soil sample $(0-25 \mathrm{~cm})$ was randomly collected from a red mud polluted field in Ajka, Hungary $\left(47^{\circ} 5^{\prime} 3.97^{\prime \prime} \mathrm{N}, 17^{\circ} 28^{\prime} 30.08^{\prime \prime} \mathrm{E}\right)$. After sampling, a portion of soil sample was sieved through $2 \mathrm{~mm}$ in order to separate plant debris and visible fauna, and then stored at $4^{\circ} \mathrm{C}$. Red mud polluted soil was autoclaved at 121.5 ${ }^{\circ} \mathrm{C}$ and $1.5 \mathrm{~atm}$. for $1 \mathrm{~h}$ for three consecutive days with incubation at $28^{\circ} \mathrm{C}$ between autoclaving. After steaming process ten-fold serial dilutions of the samples were made by mixing the soil with sterile water shaking for $15 \mathrm{~min}$ at $150 \mathrm{rpm}$, and then plating on sterile sucroseminimal salts low-phosphate (SLP) medium (sucrose $1 \%$; (NH4) SO $_{4} 0.1 \% ; \mathrm{K}_{2} \mathrm{HPO}_{4} 0.05 \% ; \mathrm{MgSO}_{4} 0.05 \%$; $\mathrm{NaCl} 0.01 \%$; yeast extract $0.05 \% ; \mathrm{CaCO}_{3} 0.05 \% ; \mathrm{pH}$ 7.2) (Sheng et al., 2008). The plates were incubated at $28{ }^{\circ} \mathrm{C}$ for 3-4 days waiting if any microbe growing. Only colony was grown (A4). Hereinafter this strain was observed in detail.

\subsection{Salt tolerance}

$\mathrm{NaCl}(0,01 \%, 2 \%, 5 \%, 7 \%, 10 \%)$ were added to liquid sucrose-minimal salts low-phosphate (SLP) medium. The medium was inoculated with bacteria in Log phase. Incubation $27 \mathrm{C}^{\circ}$ on orbital shaker $(80$ rpm) was for 24 hour. OD was measured on $600 \mathrm{~nm}$ by spectrophotometer (Amersham Biosciences Ultrospec 2100 Pro UV/Visible).

\section{3. pH tolerance}

The $\mathrm{pH}$ of liquid sucrose-minimal salts low-phosphate (SLP) medium was set on wide range of $\mathrm{pH}$ as 3.2, 4.2, 7.2, 11.2, 12.2, 13,2. The medium was inoculated with bacteria in Log phase. Incubation $27{ }^{\circ} \mathrm{C}$ on orbital shaker ( $80 \mathrm{rpm}$ ) was for 24 hours. OD was measured on $600 \mathrm{~nm}$ by spectrophotometer (Amersham Biosciences Ultrospec 2100 Pro UV/Visible).

\subsection{Oxidative stress}

Increasing concentrations of hydrogen-peroxide (880,

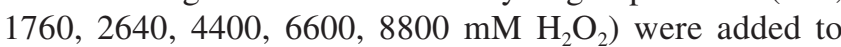
liquid SLP medium. The medium were inoculated with bacteria in Log phase. Incubation $27{ }^{\circ} \mathrm{C}$ on orbital shaker (80 rpm) in dark. Sampling was hourly and the OD was measured.

\subsection{Characterization Based on 16S rDNS Gene Sequencing and Phylogenetic Analyses}

DNA isolation from A4 bacterial strain was performed by Fermentas genomic DNA purification kit. The concentration of DNA was measured by spectrophotmetric method (Amersham Biosciences Ultrospec Nanodrop). The $16 \mathrm{~S}$ rDNS region were amplificated by PCR reaction using $27 \mathrm{f}$ and 1492r universal primers. Sequence of $27 \mathrm{f}$ primer: 5'-GAGTTTGATCACTGGCTCAG-3' and sequence of 1492r primer: 5'- TACGGCTACCTTGTTACGACTT-3'. 
The PCR reaction program was the next: $95^{\circ} \mathrm{C} 3 \mathrm{~min}, 95$ ${ }^{\circ} \mathrm{C} 0,5$ min., $54{ }^{\circ} \mathrm{C} 0,5$ min., $75^{\circ} \mathrm{C} 1$ min-, $72{ }^{\circ} \mathrm{C} 10$ min., $4 \mathrm{C} \infty$. MJ Research Minicycler machine was used. The PCR product were purificated by Thermoscientific GeneJet PCR Purification kit. The qualitative and quantitative checking of PCR product were fullfilled on $1 \%$ agarose gel. Partial sequencing was performed. The consensus gene sequences were used to identify the bacterial isolates with BLASTn analysis using NCBI GenBank nrdatabase and obtained the homology. The phylogenetical analysis was done in MEGA5.2 program aligned using multiple alignment software, Clustal W. These alignment results were used to construct phylogenetic tree using MEGA 5.2 software tool.

\subsection{Observation of halotolerant bacterium inoculation effects on Arundo growth under salt stress in gnoto- biotic conditions}

The experimental layout was a completely randomized design with three replications. To test the root elongation and growth promotion of Arundo plants by isolated bacterium under salt stress in gnotobiotic conditions, the following concentrations of $\mathrm{NaCl} 0.0 ; 0.1 ; 0.2 ; 0.3 ; 0.5 ; 1.0 \%$ were to sterilize plastic pots containing $500 \mathrm{~g}$ of acid-washed and sterilize sand. The pots were irrigated and left for the next morning where three identical sterilize seedlings of Arundo were transplanted. Examined pots were divided into two portions; the first portion received $10 \mathrm{ml}$ of inocula $\left(10^{8} \mathrm{CFU} / \mathrm{ml}\right)$, the second portion was left as control. All of tested pots were kept under greenhouse conditions. Four weeks later, the Arundo plants were evaluated, since plant length, number of shoots, number of leaves and length of new shoots were measured.

\subsection{Plant Material}

The plant material used for the current study was somatic embryo-derived plantlets of the Blossom ecotype of giant reed (Arundo donax L.) obtained from the University of South Carolina (Marton and Czako, 2004; 2007) and propagated in the Ottó Orsós Laboratory, Department of Plant Biotechnology, Debrecen University, Hungary.

\subsection{Observation of halotolerant bacterium inoculation effects on radish seed germination under salt stress in in vitro conditions}

Sterile radish (Raphanus sativus) seed sowing were performed on half-strength MS medium (Murashige \& Skoog, 1962) with added $0 ; 0,05 ; 0,1 ; 0,2 \% \mathrm{NaCl}$. The surface of the seeds were sterilized with $40 \%$ commercial bleach for $20 \mathrm{~min}$ thereafter rinsed with sterile distilled water for three times. Before sowing half part of seeds were inoculated in log phase bacteria suspension for $30 \mathrm{~min}$ and the other part was kept sterile. The germination time was one week.

\section{Results and discussion}

\subsection{Salt tolerance of isolated bacterium}

The salt tolerance of the isolate A4 was determined by measuring the optical density of bacterial growth on liquid SLP medium supplemented with $0.01-10 \%$ (w/v) $\mathrm{NaCl}$. The results showed that the isolated bacterium was able to grow on SLP medium plus $0.01-7 \%$ (w/v) NaCl. The highest percentage of $\mathrm{NaCl}$ to $10 \%(\mathrm{w} / \mathrm{v})$ suppressed the growth of the bacteria on SLP medium. Therefore, the population range of the bacterium A4 cultivated on SLP medium plus 5, 7, and $10 \%(\mathrm{w} / \mathrm{v}) \mathrm{NaCl}$ was investigated to confirm its tolerance. Isolated bacterium was able to grow moderately in $7 \%(\mathrm{w} / \mathrm{v})$ $\mathrm{NaCl}$ (Fig. 1). Therefore, this strain could be classified as halotolerant bacteria (Willey et al. 2009).

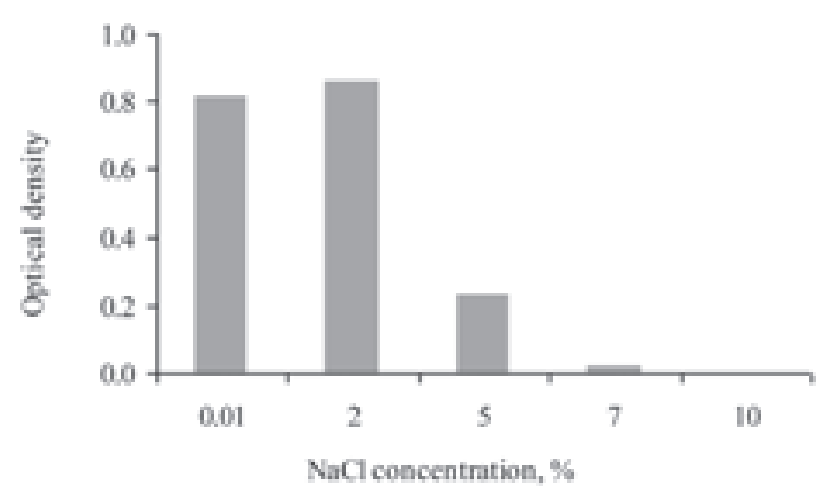

Fig. 1: The growth of isolated bacterium in liquid SLP medium supplemented with increasing $\mathrm{NaCl}$ concentrations

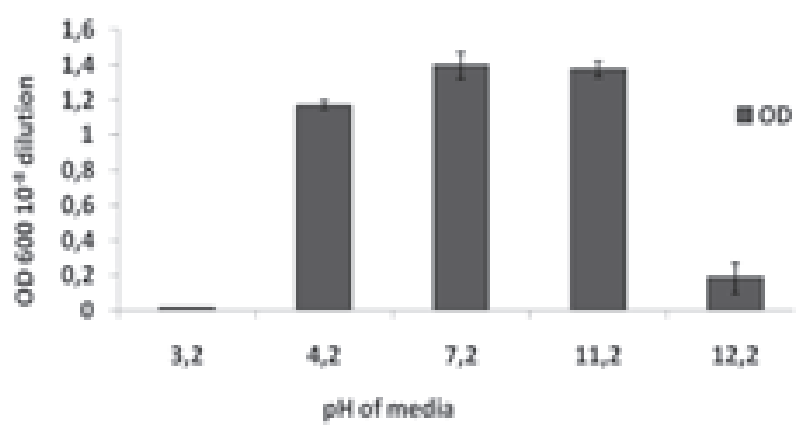

Fig. 2: The growth of tested bacterium A4 in liquid SLP medium treated with different $\mathrm{pHs}$

\subsection{Growth characteristics of Bacterium A4 under different $\mathrm{pHs}$}

The SLP liquid medium with different $\mathrm{pH}$ ranged from 3.2 to 12.2 was used to investigate the ability of isolated bacterial strain A4 to grow on different $\mathrm{pH}$. Figure 2 shows that the tested bacterium grew well at $\mathrm{pH} \mathrm{7.2,} \mathrm{as} \mathrm{well} \mathrm{as} \mathrm{its} \mathrm{ability} \mathrm{to} \mathrm{survive}$ at low and high $\mathrm{pH}, 3.2$ and 12.2 respectively. $\mathrm{pH}$ is one of the critical growth factors of microbes beside temperature, dissolved gases, osmotic pressure and water availability. Most bacteria grow best around neutral $\mathrm{pH}$ values (6.5-7.0), but some thrive 
in very acid conditions and some can even tolerate a $\mathrm{pH}$ as low as 1.0. Such acid loving microbes are called acidophiles. Even though they can live in very acid environments, their internal $\mathrm{pH}$ is much closer to neutral values.

\subsection{Tolerance of Bacterium A4 to oxidative stress}

In order to test the oxidative stress tolerance of isolated strain A4, different concentrations of $\mathrm{H}_{2} \mathrm{O}_{2}(1760,2640$, 4400, 6600, $8800 \mathrm{mM}$ ) were added to liquid SLP medium. The optical activity (OD) of liquid culture of bacterium at 600 $\mathrm{nm}$ increased during the first hour after adding $\mathrm{H}_{2} \mathrm{O}_{2}$ for all concentrations but this increasing was inversely proportional with the concentrations of $\mathrm{H}_{2} \mathrm{O}_{2}$ since high concentrations of $\mathrm{H}_{2} \mathrm{O}_{2}$ recorded low $\mathrm{OD}$. The control treatment linearly increased with the time, on the other hand the treatments with $\mathrm{H}_{2} \mathrm{O}_{2}$ did not show any increase in the next 5 hours after the beginning of the test (Fig. 3).

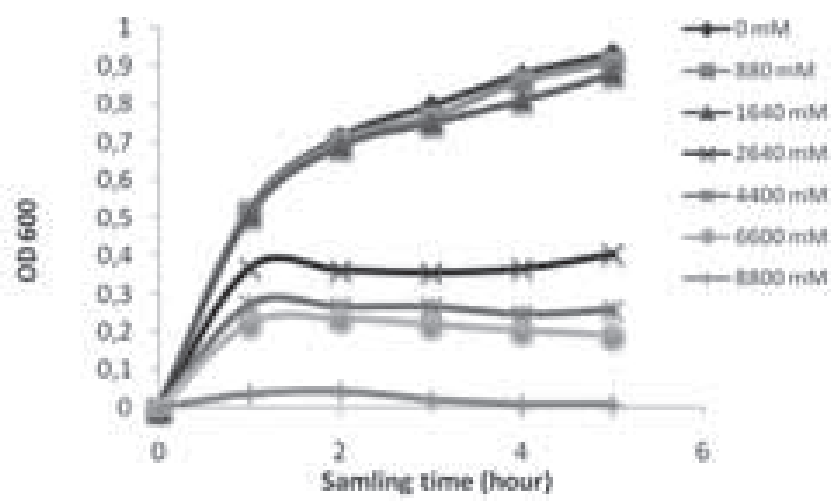

Fig. 3: Oxidative stress tolerance of bacterium A4 in liquid SLP medium supplemented by increasing concentrations of $\mathrm{H}_{2} \mathrm{O}_{2}$

\subsection{Bacterial identification}

Based on the experiments of phenotypic characterization, the isolate is gram positive and rod-shaped. The antibiotic tolerance of isolate A4 was evaluated using $200 \mathrm{mg} / \mathrm{L}$ of Kanamycin, Streptomycin, Cefotaxin and Carbanycilin. The results showed that the diameter of clear zone from isolate A4 was $1.13,1.55,4.96$ and $0.5 \mathrm{~cm}$, respectively for used antibiotics. According to these results, the isolate A4 is considered tolerant for Carbanycilin and sensitive to Cefotaxin.

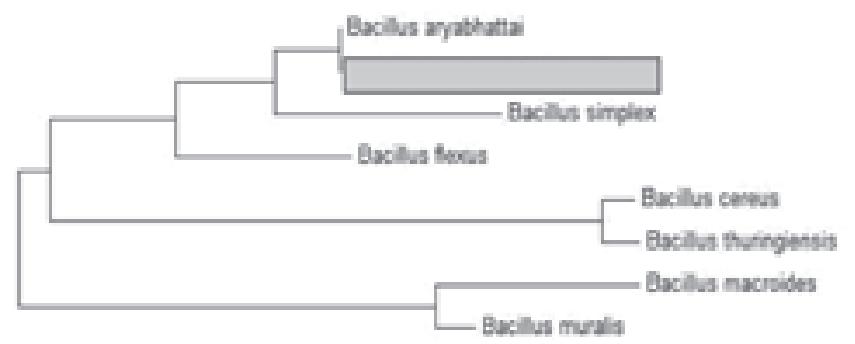

$$
\text { ato }
$$

Fig. 4: The BLASTn analysis of Bacteria A4 basis on partial sequence showed $98 \%$ similarity to the Bacillus aryabhattai bacterial strain
In addition, the $16 \mathrm{~S}$ rDNS region were amplificated by PCR reaction using $27 \mathrm{f}$ and $1492 \mathrm{r}$ universal primers. The phylogenetical analysis of observed bacterial strain confirmed our morphological characterization hence it belongs to the Bacillus genus and $98 \%$ identification was shown with Bacillus aryabhattai (Fig. 4.)

\subsection{Effect of bacterium inoculation on giant reed growth under salt stress}

More specifically, plant growth promoting bacteria received paramount attention because of its importance and ability to induce the plant growth under stresses such salinity, as well as efficient root-colonizing ability and capacity to produce a wide range of enzymes and metabolites that help plants withstand varied biotic and abiotic stresses (Vessey 2003).

Ashraf et al. (2004) suggested that inoculated selected PGPR producing bacteria could serve as a useful tool for alleviating salinity stress in salt-sensitive plants. Owing to the PGPR properties and trend to be a biofertilizer of bacteria A4, greenhouse pot experiment was carried out in order to evaluate the effect of inoculation of it on growth of giant reed plants under increasing concentrations of $\mathrm{NaCl}$. In general, increasing salt concentration decreased the plant length significantly with or without bacterial inoculation but in high concentration of $\mathrm{NaCl}$ the tested bacterium was able to keep giant reed plants servive, where this bacterium alleviated the stress of $\mathrm{NaCl}$. All of number of shoots, leaves and length of new shoot also decreased with increasing doses of $\mathrm{NaCl}$. Data in Table 1 showed that inoculation with A4 bacterial strain has alleviated the inhibiting effect of $\mathrm{NaCl}$ on growth of giant reed plants.

Table 1: Characteristics of giant reed plants inoculated by bacterium A4 under salt conditions

\begin{tabular}{|c|c|c|c|c|c|c|c|c|}
\hline \multirow[b]{2}{*}{$\begin{array}{c}\mathrm{NaCl} \\
\%\end{array}$} & \multicolumn{2}{|c|}{ Plant length } & \multicolumn{2}{|c|}{ No. of shoots } & \multicolumn{2}{|c|}{ No. of leaves } & \multicolumn{2}{|c|}{$\begin{array}{c}\text { Length } \\
\text { of new shoot }\end{array}$} \\
\hline & $\begin{array}{l}\text { with- } \\
\text { out } \\
\text { A4 }\end{array}$ & $\begin{array}{l}\text { with } \\
\text { A4 }\end{array}$ & $\begin{array}{c}\text { with- } \\
\text { out } \\
\text { A4 }\end{array}$ & $\begin{array}{l}\text { with } \\
\text { A4 }\end{array}$ & $\begin{array}{c}\text { with- } \\
\text { out } \\
\text { A4 }\end{array}$ & $\begin{array}{l}\text { with } \\
\text { A4 }\end{array}$ & $\begin{array}{c}\text { with- } \\
\text { out } \\
\text { A4 }\end{array}$ & $\begin{array}{l}\text { with } \\
\text { A4 }\end{array}$ \\
\hline 0.0 & 12.4 & 12.8 & 1.7 & 0.5 & 3.1 & 4.5 & 3.5 & 3.6 \\
\hline 0.1 & 13.9 & 6.3 & 0.6 & 0.5 & 5.7 & 2.4 & 4.4 & 3.2 \\
\hline 0.2 & 6.5 & 6.8 & 0.0 & 0.7 & 2.3 & 2.6 & 0.0 & 1.3 \\
\hline 0.3 & 5.7 & 2.8 & 0.0 & 0.0 & 2.3 & 0.7 & 0.0 & 0.0 \\
\hline 0.5 & 0.0 & 0.3 & 0.0 & 0.1 & 0.0 & 0.1 & 0.0 & 0.1 \\
\hline 1.0 & 0.0 & 0.0 & 0.0 & 0.0 & 0.0 & 0.0 & 0.0 & 0.0 \\
\hline
\end{tabular}

\subsection{Effect of Bacillus aryabhattai inoculation of Radish germination}

Besides the Arundo donax L. the presumed salt stress mitigating effect of bacterium A4 were studied in case of radish germination experiment. Basis on the results sodiumchloride was found that in $0.2 \%$ concentration totally inhibited the germination of radish seeds (with and without 
bacterial inoculation). However higher germination vigour was found in case of bacterial inoculated seeds on media completed with $0.05-0.1 \% \mathrm{NaCl}$ compare to the inoculation free seeds (Fig. 5). These results Like the experiment with Arundo, salt stress alleviating effect of bacterium A4 could be seen in lower $\mathrm{NaCl}$ concentration of media. No positive effect of bacterial inoculation was found on control media.

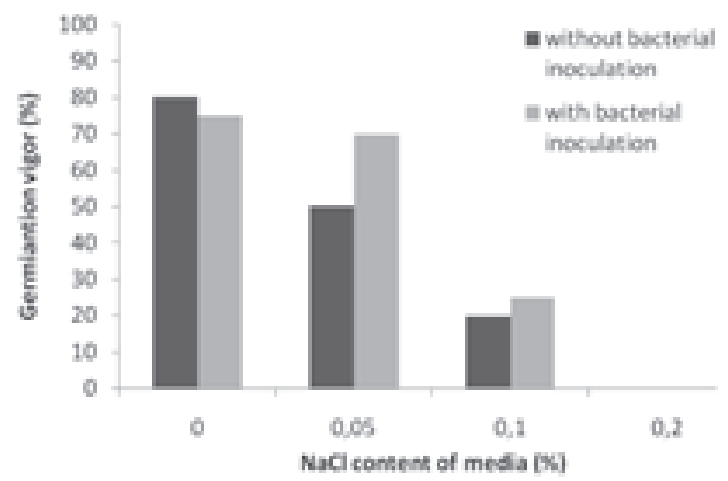

Fig. 5: Germination percent of Radish seeds on solid medium supplemented by different $\mathrm{NaCl}$ concentrations in presence of isolated bacterium A4

\section{Summary}

The present study is consider a pioneer report that highlights and studies the possible using of a stress tolerant bacterial strain as biofertilizer and PGPR with vegetable crop such radish and energytic crop such giand reed under salt stress observed. The data showed that the germination percent of radish seed under moderate concentration of $\mathrm{NaCl}$ was assisted by using the observed bacterial strain (A4).Ggiant reed growth characters were not so far for radish effect, where the vegetative parameters such plant length, number of shoots, leaves and length of new shoots where increased in salted pots with identified Bacillus strain compared to control (without bacterial inoculation). Considering the abiotic stress tolerance measurements this bacterial strain showed a great ability to grow and survive under abiotic stresses such high $\mathrm{NaCl}$ concentrations, differnt $\mathrm{pH}$ and oxidative stress with $\mathrm{H}_{2} \mathrm{O}_{2}$.

\section{Acknowledgments}

This research was realized in the frames of TÁMOP 4.2.4. A/2-11-1-2012-0001 National Excellence Program Elaborating and operating an inland student and researcher personal support system. The project was subsidized by the European Union and co-financed by the European Social Fund.

Additional financial support from the Balassi Institute, Hungarian Scholarship Board (Budapest, Hungary) is also gratefully acknowledged. We would like to thank László Márton providing the somatic embryo derived Arundo donax plants for experiments.

\section{References}

Alshaal T, Domokos-Szabolcsy É, Márton L, Czakó M, Kátai J, Balogh P, Elhawat N, El-Ramady H, Fári M (2013a): Phytoremediation of bauxite-derived red mud by giant reed (Arundo donax L.). Environ Chem Lett. 11: 295-302.

Alshaal T, Domokos-Szabolcsy É, Márton L, Czakó M, Kátai J, Balogh P, Elhawat N, El-Ramady H, Geröcs A, Fári M (2013b): Restoring soil ecosystems and biomass production of Arundo donax L. under microbial communities-depleted soil.

Ashraf M, Hasnain S, Berge O, Mahmood T (2004): Inoculating wheat seedlings with exopolysaccharide-producing bacteria restricts sodium uptake and stimulates plant growth under salt stress. Biol Fertil Soils. 40: 157-162.

Bell G (1997): Ecology and management of Arundo donax, and approaches to riparian habitat restoration in Southern California. [In: Brock JH, Wade M, Pysek P, Green D (eds) Plant Invasions: Studies from North America and Europe.] Blackhuys Publishers, Leiden. The Netherlands, pp. 103-113.

Coffman GC, Ambrose RF, Runde PW (2010): Wildfire promotes dominance of invasive giant reed (Arundo donax) in riparian ecosystems. Biological Invasions. 12: 2723-2730.

Flowers T (2004) Improving crop salt tolerance. J Exp Bot. 55: 307-319.

Günes K, Saygin Ö (1996): Productivity of the energy crops: Giant reed and sweet sorghum in Turkey. Fresenius Environmental Bulletin. 5. (11-12): 756-761.

Khan MH, Panda SK (2008): Alterations in root lipid peroxidation and antioxidative responses in two rice cultivars under $\mathrm{NaCl}$-salinity stress. Acta Physiol Plant. 30: 89-91.

Maheshwari DK (ed) (2012): Bacteria in Agrobiology: Stress Management. Springer Heidelberg Dordrecht London New York.

Márton L, Czakó M (2004): Sustained Totipotent Culture of Selected Monocot Genera. USA, patent 6, 821, 782

Márton L, Czakó M (2007): Sustained Totipotent Culture of Selected Monocot Genera. USA, patent 7, 303, 916

Munns R (2002) Comparative physiology of salt and water stress. Plant Cell Environ 25: 239-250

Murashige, T. \& Skoog, F (1962): A revised medium for rapid growth and bioassays with tobacco tissues cultures Plant Physiol. 15: 126-146.

Perdue R E (1958): Arundo donax - source of musical reeds and industrial cellulose. Economic Botany. 12: 368-404.

Richards LA (1954): Diagnosis and improvement of saline and alkaline soils. United States Salinity Lab, Riverside, CA

Sharma KP, Kushwaha SPS, Gopal B (1998) A comparative study of stand structure and standing crops of two wetland species, Arundo donax and Phragmites karka, and primary production in Arundo donax with observations on the effect of clipping. Journal of Tropical Ecology. 39: 3-14.

Sheng XF, Xia JJ, Jiang CY, He LY, Qian M(2008): Characterization of heavy metal-resistant endophytic bacteria from rape (Brassica napus) roots and their potential in promoting the growth and lead accumulation of rape. Environmental Pollution, 156:1164-1170.

Tucker GC (1990): The genera of Arundinoideae (Gramineae) in the southern United States. Journal of the Arnold Arboretum. 71:145163.

Vessey JK (2003) Plant growth promoting rhizobacteria as biofertilizers. Plant Soil. 255:571-586.

Willey JM, Sherwood LM, Woolverton CJ (2009) Prescott's principles of microbiology. New York: McGraw-Hill. Vessey JK. 2003. Plant growth promoting rhizobacteria as biofertilizers. Plant Soil. 255: 571-586. 